\title{
INFECCIONES DEL TRACTO URINARIO EN PACIENTES CON DIABETES. PARTE 1
}

\section{URINARY TRACT INFECTIONS IN PATIENTS WITH DIABETES. PART 1}

\author{
Comité de Nefropatía Diabética de la Sociedad Argentina de Diabetes \\ Expertos: Alicia Elbert ${ }^{1}$, Diego Yahni ${ }^{2}$ \\ Participantes: María Florencia Aranguren, Bárbara Arinovich, Teresa Bensusan, Guillermo De’Marziani, \\ Gabriela Medek, Estrella Menéndez, María José Pomares, Jimena Soutelo, Fabiana Vázquez, Gloria Viñes \\ Coordinadoras: Fabiana Dávila ${ }^{3}$, Yanina Castaño ${ }^{4}$
}

\section{RESUMEN}

Las infecciones del tracto urinario (ITUs) son frecuentes en la práctica médica diaria. Existen factores patogénicos que modulan el riesgo de su aparición que dependen del germen responsable y el huésped. La diabetes mellitus es un factor predisponente para la aparición de infecciones urinarias. Como factores de riesgo para estas infecciones se mencionan la mayor duración de la diabetes, la albuminuria y neuropatía con menor vaciamiento vesical, siendo controversial la presencia de glucosuria. Según su ubicación en el árbol urinario pueden ser bajas y altas, y de acuerdo a la severidad, complicadas o no. La bacteriuria asintomática, detectada por análisis rutinario, es más frecuente en mujeres con diabetes. La elección del esquema antibiótico en las infecciones urinarias se basa en la severidad de la infección, el antecedente de microorganismos resistentes y la sensibilidad en el antibiograma, recordando ajustar la dosis de acuerdo al grado de insuficiencia renal.

En este trabajo nuestro objetivo es describir las características clínicas y el diagnóstico para un adecuado tratamiento antibiótico.

Palabras clave: diabetes; infección del tracto urinario; bacteriuria; enfermedad renal crónica.

Revista de la Sociedad Argentina de Diabetes 2019; Vol. 53 (28-50)

\section{ABSTRACT}

Urinary tract infections (UTIS) are frequent in daily medical practice. There are pathogenic factors that modulate the risk of their onset depending on the responsible germ and host. Diabetes mellitus is a predisposing factor for developing urinary infections. The longest duration of diabetes, albuminuria and neuropathy with less bladder emptying are mentioned as risk factors for these infections, being controversial the presence of glycosuria. Depending on their location in the urinary tract, infections can be lower and upper tract infections, and according to severity, complicated or not. Asymptomatic bacteriuria, detected by routine urinalysis, is more frequent in women with diabetes. The choice of the antibiotic scheme in urinary tract infections is based on the severity of the infection, history of resistant microorganisms and sensitivity in the antibiogram, adjusting the dose according to the degree of renal insufficiency. The aim of our work is to describe the clinical characteristics and diagnosis for an adequate antibiotic treatment.

Key words: diabetes; urinary tract infection; bacteriuria; chronic renal disease.

Revista de la Sociedad Argentina de Diabetes 2019; Vol. 53 (28-50)
Médica especialista en Nefrología, Directora del Centro de Enfermedades Renales e Hipertensión Arterial, Ciudad Autónoma de Buenos Aires, Argentina

2 Médico Infectólogo, Médico de Planta en Infectología, Hospital General de Agudos Vélez Sarsfield, Médico del staff de Infectología del CEMIC, miembro de la Sociedad Argentina de Infectología, Ciudad Autónoma de Buenos Aires, Argentina

3 Médica especialista en Nutrición, especializada en Diabetes, Servicio de Diabetes, Hospital Universitario Austral, Provincia de Buenos Aires, Argentina

4 Médica especialista en Nutrición, Magister en Diabetes, Coordinadora del Área de Diabetes del Centro de Diálisis CETRO (Centro de Estudios y Tratamiento Renal Olavarría), Provincia de Buenos Aires, Argentina
Contacto: Alicia Elbert, Diego Yahni

E-mail: alicia.elbert.nd@gmail.com/diegoyahni@hotmail.com Conflictos de interés: los autores declaran que no existe conflicto de interés. 


\section{INTRODUCCIÓN}

Las infecciones del tracto urinario (ITUs) son una de las enfermedades más prevalentes en el mundo, y consisten en la colonización y multiplicación microbiana, habitualmente bacteriana. Los datos epidemiológicos demuestran una mayor incidencia de ITUs en la población con diabetes meIlitus (DM) tipo 1 y 2 , siendo más prevalente con la edad, género femenino, mal control glucémico y deterioro de la función renal. Las ITUs pueden clasificarse por el nivel anatómico, su grado de severidad y los factores de riesgo para una infección.

Ante la situación de mal control metabólico, hiperglucemia/hipoglucemia o estados hiperosmolares o cetoacidosis es necesario realizar un diagnóstico temprano de posible ITU, por ende su reconocimiento precoz y adecuado manejo son importantes.
Las características clínicas y los datos de laboratorio se centran en el nivel anatómico y el grado de gravedad de la infección. En la evaluación clínica de rutina, antes de establecer un diagnóstico, debe considerarse una serie de criterios básicos que incluyen:

- Síntomas clínicos.

- Resultados de pruebas de laboratorio.

- Evidencia de la presencia de microorganismos mediante cultivos u otras pruebas específicas.

Debido al crecimiento sostenido de la DM a nivel mundial -y por ende la enfermedad renal por diabetes como causa principal de insuficiencia renal crónica (IRC)- será cada vez más habitual tratar pacientes con ambas patologías, grupo que presenta mayor susceptibilidad a las infecciones, y principalmente a las del tracto urinario.

\title{
INFECCIONES DEL TRACTO URINARIO EN PACIENTES CON DIABETES. GENERALIDADES
}

\section{URINARY TRACT INFECTIONS IN PATIENTS WITH DIABETES. OVERVIEW}

\author{
Jimena Soutelo ${ }^{1}$
}

\section{RESUMEN}

La infección del tracto urinario (ITU) reside en la colonización y mutiplicación de microorganismos en el tracto urinario. Se diagnostica por cultivo bacteriano y se clasifica según la localización anatómica y la severidad que determinan los signos, síntomas y gravedad de la infección, recurrencia y factores de riesgo. Las ITUs más frecuentemente adquiridas ocurren en la comunidad. Existe mayor incidencia de este tipo de infecciones en las personas con diabetes mellitus, siendo más prevalente con la edad, género femenino, mal control glucémico y pobre función renal.

Palabras clave: infección del tracto urinario; diabetes mellitus; clasificación anatómica; grados de severidad.

Revista de la Sociedad Argentina de Diabetes 2019; Vol. 53 (28-50)

\begin{abstract}
The urinary tract infection (UTI) lies in the colonization and multiplication of microorganisms in the urinary tract. It is diagnosed by bacterial culture and classified according to the anatomical location and the severity determining the signs, symptoms and severity of the infection, recurrence and risk factors. The most frequently acquired UTIs occur in the community. There is a higher incidence of this type of infection in people with diabetes mellitus, being more prevalent with age, female gender, poor glycemic control and poor renal function.
\end{abstract}

Key words: urinary tract infection; diabetes mellitus; anatomical classification; severity scale.

Revista de la Sociedad Argentina de Diabetes 2019; Vol. 53 (28-50)
Médica especialista en Endocrinología, Servicio de Endocrinología, Hospital Churruca Visca, Jefa de Trabajos Prácticos del Departamento de Fisiología, Unidad Académica 2, Universidad de Buenos Aires, Ciudad Autónoma de Buenos Aires, Argentina
Contacto de la autora: Jimena Soutelo

E-mail:mjimenasoutelo@gmail.com

Correspondencia: Uspallata 3400 (C1437JCP), Ciudad Autónoma de Buenos Aires, Argentina

Fecha de trabajo recibido: 25/03/19

Fecha de trabajo aceptado: 03/04/19

Conflicto de interés: la autora declara que no existe conflicto de interés 